\title{
AN ALTERNATIVE MODEL OF CHILD SEXUAL ABUSE HANDLING POLICYIN INDONESIA
}

\author{
Rd. Ahmad Buchari., Asep Sumaryana. dan Rosita Novi Andari \\ Public Administration Departement, Fakulty of Social and Political Sciences \\ Padjadjaran University of Bandung \\ E-mail: ahmad.buchari@unpad.ac.id
}

\begin{abstract}
Child sexual abuse is one of the forms of crimes against children that call for serious attention of the government. Indonesian Commission for Child Protection (KPAI)'s 2011-2016 years data shows that the number of child sexual abuse victims has been fluctuating year by year. The objectives of the present research were to evaluate the output of the implementation of government policies on handling child sexual abuses during 2011-2014, and to develop an alternative model of child sexual abuse handing policy suitable to apply in Indonesia. The research used a descriptive qualitative approach with a data collection technique of documentation and a descriptive data analysis. The research findings revealed that the policies currently pursued were generally ineffective both in prevention and in law enforcement against the offenders. Therefore, a model of child sexual abuse handling policy in Indonesia by a systems approach can be made as an alternative model of policies in dealing with the problem.
\end{abstract}

Key words: child sexual abuse, public policy evaluation, government policies, policy model.

\section{PENGEMBANGAN ALTERNATIF MODEL KEBIJAKAN PENANGANAN KEJAHATAN KEKERASAN SEKSUAL ANAK DI INDONESIA}

\begin{abstract}
ABSTRAK. Masalah kekerasan seksual terhadap anak merupakan salah satu bentuk kejahatan terhadap anak yang memerlukan penanganan serius dari pemerintah. Data Komisi Perlindungan Anak Indonesia tahun 2011-2016 menunjukkan jumlah anak sebagai korban dari kejahatan kekerasan seksual mengalami perkembangan yang fluktuatif setiap tahunnya. Penelitian ini bertujuan untuk mengevaluasi hasil penerapan kebijakan pemerintah dalam upaya penanganan kekerasan seksual terhadap anak selama tahun 20112014 dan mengembangkan alternatif model kebijakan penanganan kejahatan kekerasan seksual terhadap anak untuk diterapkan di Indonesia. Penelitian ini menggunakan pendekatan kualitatif yang bersifat deskriptif dengan teknik pengumpulan data melalui dokumentasi dan analisis data bersifat deskriptif. Hasil penelitian menunjukkan bahwa hasil (output) kebijakan yang diterapkan saat ini cenderung belum efektif baik dalam hal pencegahan maupun penegakan hukum terhadap penindakan para pelaku tindak kejahatan tersebut. Oleh karena itu, penerapan model kebijakan penanganan kejahatan kekerasan seksual terhadap anak di Indonesia dengan pendekatan sistem dapat dijadikan alternatif model kebijakan untuk mengatasi permasalahan tersebut.
\end{abstract}

Kata kunci: kekerasanseksualterhadapanak, evaluasikebijakanpublik, kebijakan pemerintah, model kebijakan.

\section{INTRODUCTION}

Child sexual abuse is one of the forms of crimes against children that call for serious attention of the government. According to the definitions offered by Muhammad Zainuddin (2015), WHO (in Suradi, 2013), and Law No. 35 of 2014 on Amendment of Law No. 23 of 2002 on Child Protection, meant by child sexual abuse is criminal behaviors engaging children (persons under 18 years old, including fetus) in sexual activities, that is, in forms of profane behaviors by others, activities leading to pornography, porno talks, and engaging children in prostitution business which cause misery or physical, behavioral, cognitive, and social-emotional (psychic) sufferings.(Buchari. $2016: 235$ - 239)

In general, the statistic of sexual abuses in the world showed that $19.7 \%$ of girls and $7.9 \%$ of boys have suffered sexual abuses. Geographically, the highest prevalence of child sexual abuses is found in Africa (34.4\%) (http://www.koran sindo.com). The problems of child sexual abuses in Indonesia can be seen from the cases of child sexual abuses. According to the Chairman of National Commission of Child Protection
(Komnas PA), Aris Merdeka Sirait, since 2015 till April 2016 there were 312 child abuse cases, of which 51\% or 150 cases were child sexual abuses. The number is already high enough but it potentially rises even higher, spreading evenly in urban and rural areas (http://m. republika.co.id). Meanwhile, based on KPAI data, the growth in the numbers of children who suffered sexual abuses (rape, molestation, sodomy/pedophilia, etc.) from 2011-2016.

From the above it could be seen that the number of children who suffered sexual abuses was fluctuating, i.e., it increased from year 2011 to year 2012, decreased in 2013, and then increased again in 2014 to the highest number of cases by 656 , and then decreased again in 2015 to be 218 cases. The number of child sexual abuse cases in the current year (2016) was 29. The culmination of child sexual abuse cases that drew public attention and even the President attention is a sexual abuse and murder of a 14-year old girl, Yuyun, in Bengkulu in May 2016, committed by teens of student boys. In this case, the President instructed that the offenders be arrested and punished as harsh as possible (http://www.dw.com/id) 
To handle the problem, the government is under obligation and responsible to provide protection to children against among others sexual abuse. This is laid down in Law No. 35 of 2014 on Amendment of Law No. 23 of 2002 on Child Protection, articles 15, 20, and 59. One of the policies that the government pursues in responding to the cases of child sexual abuse committed massively and accompanied by murder and much other violence is by enacting Government Regulation to Replace Law (PERPU) Number 1 of 2016 on Second Amendment of Law No. 23 of 2002 on Child Protection, dubbed PerpuKebiri(Castration Perpu). In a course of Plenary Cabinet Meeting on Tuesday, 10 May 2016, Republic of Indonesia President, Joko Widodo, asserted that child sexual abuses have been extraordinary ones and hence should be handled by equally extraordinary way (http:// presidenri.go.id). Therefore, the government perceived them as an urgent condition, and then the President instructed several ministries, among them Coordinating Ministry of Human and Culture Development (Kemenko PMK), Ministry of Woman Empowerment and Child Protection (Kemen PPPA) and Ministry of Social Affairs (Kemensos) to immediately prepare a draft PERPU providing for the aggravated punishment (sanction) against the offenders in child sexual abuse cases. The Perpu was ratified by DPR (Parliament) on 12 October 2016 (http://www.bbc.com/).

\section{Formulation of Problem}

1. What is the output of Government policy in handling child sexual abuse thus far?

2. What is the model of child sexual abuse handling policy which may come to be an alternative suitable to apply in Indonesia?

To find out the output of the implementation of government policy in dealing child sexual abuse thus far, it needs to evaluate the current policy of handling children. However, before such evaluation, it needs to firstly identify the child sexual abuse handling policy currently pursued. The evaluation here focuses more on evaluating the implementation of the policy or after the policy has already been implemented for a specific time period (ex-post evaluation) by analyzing the output of the child sexual abuse handling policy in Indonesia. The output of the policy evaluation would used as a basis in formulating further policies by developing an alternative model of child sexual abuse handling.

\section{Evaluation of the Output of Public Policy}

Theoretically, an evaluation in a public policy analysis is about producing information concerning the value or benefit of a policy output. A policy output has a real value if it contributes to the desired goal or target. In this case it can be said that the policy has achieved a significant performance, meaning that the policy problems have been cleared or overcome. An evaluation serves to produce information about the extent certain goals and targets of the policy have achieved and to offer contribution, clarification, and critique on the values on which goal and target setting is based. (Achdiat, 2017: 140-148) There are six criteria of evaluation to use in evaluating the output of a policy, namely: effectiveness, efficiency, adequacy, leveling, responsiveness, and accuracy (Dunn, 2003:608-611). Evaluation is an assessment of the performance of an implementation. It can be carried out after an activity has already been completed. By completed is meant here as (1) time (has reached/surpassed a time limit) and (2) work (work has been finished) (Nugroho, 2014:706). Moreover, an evaluation after the implementation of policy is also called a consequence evaluation (policy output) and/ or impact (output) evaluation of policy as a summative evaluation (Nugroho, 2014:713).

Wollmann Hellmut suggests that an ex-post evaluation is one serving (1) to assesses to the extent of which the desired goal of a policy has been achieved and (2) to answer clausal questions such as what are the effects and changes observed as really related (causally) to the policy or program. To analyze an evaluation of a finished policy, a meta-evaluation can be used. A meta-evaluation is intended to analyze (primary) evaluation by using a secondary analysis. There are two variants of metaevaluation, first, a meta-evaluation that is able to review the finished part of a primary evaluation, what it looks like according to the criteria and standard of methodology (methodological meta-evaluation) and, second, a metaevaluation maybe ought to collect substantive findings of finished (primary) evaluation and synthesize the results (synthetic meta-analysis) (Fisher dkk, 2015:555-556).

Because the present research focused more on the evaluation of policy output, a formal evaluation approach in form of retrospective output evaluation was selected as an approach in doing evaluation. According to Dunn (2003:611-618)), a formal evaluation approach uses a descriptive method to produce valid, reliable information on the policy output formally announced as the goal of program-policy. An evaluation of retrospective output includes the forms of monitoring and evaluation of output, but it is not accompanied by a direct control of inputs and processes of policy that may be manipulated.

\section{Public Policy Formulation Model}

Public policy with a systems model like one developed by Easton assumes that a policy is the output of a political system comprising input, throughput, and output. In the systems model, the public policy formulation process is within political system by relying on inputs consisting of two things, namely demands and supports (Nugroho, 2014:516). The systems model is beneficial in helping organize an investigation into the 
development of a public policy. In addition, it gives a rise to awareness of some important aspects of policy formulation process such as how do environmental inputs affect the substances of both public policy and nature of political system? What forces or factors are originated in environment that play crucial role in driving the emergence of demands on a political system (Winarno, 2012:100). Indiahono, 2009, develops a method of using the public policy formulation model by applying Easton's model and Ripley's policy stage model. The latter consists of (1) preparation of government agenda, (2) government agenda, (3) policy formulation and legitimacy, and (4) policy. The long cycle of policy is the four stages plus (1) policy implementation, (2) policy action, (3) policy performance and impact, (4) evaluation of implementation, performance, and policy impact, and (5) decision on the future of policy (new decision). The methods of the conceptual application of Easton's and Ripley's models can simply be seen on the Table1 below:

Table 1. Conceptual Application of Easton's and Ripley's Models

\begin{tabular}{|c|c|c|}
\hline No. & Aspect & Scope \\
\hline 1 & $\begin{array}{l}\text { Environment } \\
\text { of Policy }\end{array}$ & $\begin{array}{l}\text { The problem setting of actors } \\
\text { and predominant actors } \\
\text { (political power structure, } \\
\text { lawmakers, college students, } \\
\text { journalists, and other interest } \\
\text { groups) }\end{array}$ \\
\hline 2 & Agenda Setting & 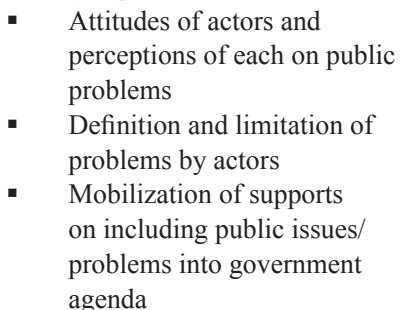 \\
\hline 3 & $\begin{array}{l}\text { Formulation } \\
\text { and Legitimacy }\end{array}$ & 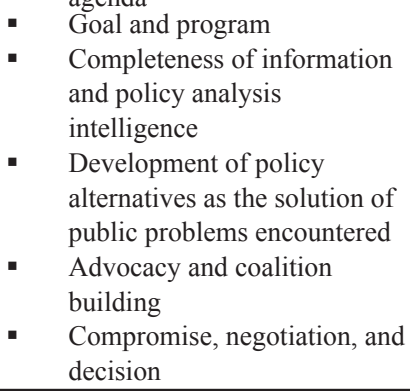 \\
\hline
\end{tabular}

Source: In Indiahono, (2009:27-28)

These Easton's and Ripley's models would then be applied in developing alternative model of child sexual abuse handling policy in Indonesia.

\section{METHOD}

The present research used a qualitativedescriptive approach, i.e., an approach that describes what the output of the implementation of government policy on child sexual abuse handling in Indonesia is.
Qualitative approach uses those methods which explore and understand meanings that are, by some individuals or groups - attributed to social or humanity problems (Creswell,2016:4). Descriptive research is one that describes a phenomenon situation in detail, emphasizing more on answering the questions of "how" and "who", starting with defining the subject and then describing it accurately (Suharsaputra, 2012:38).

The locus and focus of the research analysis units was child sexual abuse handling policy at national level, including Criminal Code (KUHP), UU No. 23 of 2002 on Child Protection, Presidential Instruction No. 5 of 2014 on National Movement of Anti-Child Sexual Abuse (GN-AKSA), Law No. 35 of 2014 on Amendment of Law No. 23 of 2002 on Child Protection and Government Regulation to Replace Law (PERPU) Number 1 of 2016 on Second Amendment of Law No. 23 of 2002 on Child Protection.

The data collection technique used was documentation, one of the commonly used data collection techniques in qualitative researches (Creswell, 2016:255). Documentation was done by collecting public documents such as legislations, PP\&PA ministry's reports, and relevant documents as a material used in developing a theoretical basis, framework of thought, and data analysis related to the studied problems. Data analysis was carried out by analyzing how the regulations are laid down in various child sexual abuse handling policies and what are the outputs of the implementation of the policies. Next, a conclusion was drawn and recommendation was proposed in relation to the formulation of further policy by developing an alternative model of child sexual abuse handling policy in Indonesia.

\section{RESULTS AND DISCUSSION}

\section{Evaluation of the Output of Child Sexual Abuse Handling Policy in Indonesia Currently}

The handling of child sexual abuses in Indonesia initially referred to the provisions of criminal law as laid down in Criminal Code (KUHP). Then, over time, a special policy on child protection was stipulated in Law No. 23 of 2002 on Child Protection as amended by Law No. 35 of 2014 on Amendment of Law No. 23 of 2002 on Child Protection. In addition, Presidential Instruction No. 5 of 2014 on National Movement of Anti-Child Sexual Abuse (GN-AKSA) was issued. The policy stipulated in the provisions of KUHP and the Law contains among others the forms of child sexual abuse and sanctions against the offenders of child sexual abuse, while the policy stipulated in the Presidential Instruction contains instructions to Ministers, General Attorney, Head of Police, Heads of Non-departmental Public Agencies, Governors, and Regents/Mayors to take measures required according to their own duties, functions, and authorities in coordinated and integrated 
ways in a bid to prevent and eradicate child sexual abuse by GN-AKSA involving all communities and businesses elements. The child sexual abuse handling policy currently implemented refers to Law No. 35 of 2014.

According to the Law, intended by child protection is any activities taken to secure and protect children and their rights so as to give them with a chance of living, growing, developing, and participating optimally according to human honor and prestige, and to get protection against violence and discrimination. Child rights are part of basic human rights that should be protected and fulfilled by parents, families, society, nation, government, and regional government. Meanwhile, special protection is a form of protection received by children in particular situations and conditions against any threats that endanger themselves during their growth. Some forms of protection secured by the Law to children against sexual abuse are as follows:

a. Each child has a right to receive protection against sexual abuse (article 15).

b. Each child who suffers or turn into be the offender of sexual abuse or is inflicted in a legal case should be kept in confidence (article 17).

c. Children inside or within an educational unit area should receive protection against physical, psychic, sexual, and other abuses committed by educators, educational staff, schoolmate, and/or others (article 54).

d. Specialized child protection should be given to children who are subject to sexual abuse (article 59). The specialized protection is an obligation and responsibility of both government and society performed by: (1) education on reproductive health, religious values, and moral values, (2) social rehabilitation, (3) psychosocial advocacy during a treatment till recovery, (4) offering protection and advocacy at each level of legal proceedings from investigation by police, prosecution by attorneys, to court hearings by judges (articles 66 and 69A).

The Law lays down some penal provisions on the offenders of child sexual abuse, as contained on the table 2 below.

From the Law it can be seen that the provisions on the sanctions against child sexual abuse that currently prevail are an imprisonment for no less than 5 years and no more than 15 years and a fine of no less than $\mathrm{Rp}$. $60,000,000$ and no more than Rp. 300,000,000.00. These penal sanctions are generally severer that that apply earlier in both Criminal Code and Law No. 23 of 2002 as shown on the table 3 below:

\section{Table 2. Penal Provision in Law No. 35 of 2014 on Amendment of Law No. 23 of 2002 on Child Protection}

\begin{tabular}{|c|c|c|}
\hline No & Prohibition & Penal Provision \\
\hline 1. & $\begin{array}{l}\text { Anyone is prohibited from putting, leaving, } \\
\text { committing, asking to commit, or taking part in } \\
\text { committing abuse against a child (Article } 76 \mathrm{C} \text { ) }\end{array}$ & $\begin{array}{l}\text { - Imprisonment for no more than } 3 \text { (three) years and } 6 \text { (six) months and/ } \\
\text { or a fine of no more than Rp72,000,000.00 (seventy two million). } \\
\text { - In case the child suffer severe injury, the offender is sentenced by: } \\
\text { Imprisonment for no more than } 5 \text { (five) years and/or a fine of no more } \\
\text { than Rp100,000,000.00 (one hundred million rupiah). } \\
\text { In case the child dies, the offender shall be sentenced for no more than } \\
15 \text { (fifteen) years and/or a fine of no more than Rp3,000,000,000.00 } \\
\text { (three billion rupiah). } \\
\text { - The sentence shall be aggravated by a third of the threatened sentence if } \\
\text { the offender is her or his parent. }\end{array}$ \\
\hline 2. & $\begin{array}{l}\text { Anyone is prohibited from committing violence } \\
\text { or threatened violence, forcing a child to have } \\
\text { sexual intercourse with him or her or with other } \\
\text { (article } 76 \text { D) }\end{array}$ & $\begin{array}{l}\text { - Imprisonment for no less than } 5 \text { (five) years and no more than } 15 \\
\text { (fifteen) years and a fine of no more than Rp5,000,000,000.00 (five } \\
\text { hundred million rupiah). } \\
\text { Penal provision also applies to anyone who intentionally commits } \\
\text { deception, a series of lies, or persuading a child to have sexual } \\
\text { intercourse with him or her or other. } \\
\text { In case the crime is committed by the child's parent, guardian, baby } \\
\text { sitter, educator, or educational staff, the sentence is aggravated by } 1 / 3 \text { (a } \\
\text { third) of threatened sentence. }\end{array}$ \\
\hline 3 & $\begin{array}{l}\text { Anyone is prohibited from committing violence } \\
\text { or threatened violence, forcing, committing } \\
\text { deception, a series of lies, or persuading a child } \\
\text { to have or leaving to have indecent behavior } \\
\text { (article } 76 \mathrm{E} \text { ) }\end{array}$ & $\begin{array}{l}\text { - Imprisonment of no less than } 5 \text { (five) year and no more than } 15 \text { (fifteen) } \\
\text { year and a fine of no more than Rp5,000,000,000.00 (five hundred } \\
\text { million rupiah). } \\
\text { In case the crime is committed by the child's parent, guardian, baby } \\
\text { sitter, educator, or educational staff, the sentence is aggravated by } 1 / 3 \text { (a } \\
\text { third) of threatened sentence. }\end{array}$ \\
\hline
\end{tabular}

Source: processed from Law No. 35 of 2014 on Amendment of Law No. 23 of 2002 on Child Protection. 
Table 3. Provisions on the penal sanctions of child sexual abuse

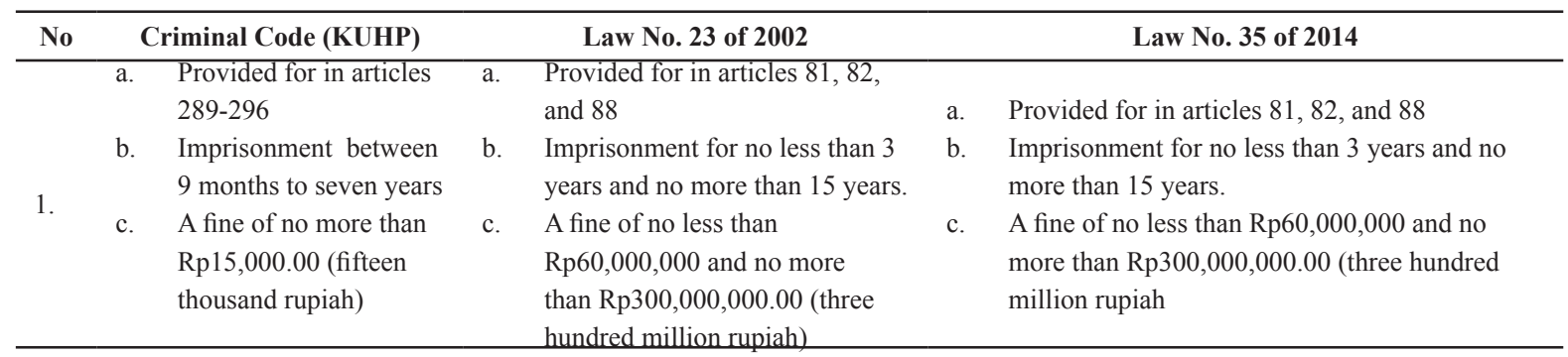

Source: processed from KUHP, Law No. 23 of 2002, and Law No. 35 of 2014.

To find out the output of the implementation of child sexual abuse handling policy in Indonesia, it could be analyzed from a report of the profile and development of those children who need special protection from government, i.e., children who are subject to sexual abuse as contained in books of Profile of Indonesian Children Year 2012 (Yusuf, 2012:7 and 64) and Profile of Indonesian Children Year 2015 (Naim, 2015:8 and 7173). In general, from the two reports it could be found out that, in 2011, Indonesia's 0-17 year old population was 82.6 million or $33.9 \%$ of total population of $243.3 \%$. Susenas data shows that the number of children who were subject to crimes during 2011 was 385.5 thousand, of which $61.3 \%$ (236.5 thousand) lived in urban areas and the remaining $38.7 \%$ (149 thousand) in rural areas. Meanwhile, in 2014, Indonesia's 0-17 year old was 82.8 million or $32.9 \%$ of total population of 252.165 million. Susenas data also shows that children who were subject to crimes during 2014 was 247.6 thousand, of which 63.52 (157.2 thousand) lived in urban areas and the remaining $36.49 \%$ (90.4 thousand) in rural areas. The types of crimes experienced by the children include crimes such as theft, rape, drug abuse, violence against women and children, domestic violence, abandonment of children, and child trafficking. There is no yet, however, a breakdown of the numbers of the children who suffered each type of crimes, as the number of children who experienced sexual abuses. Nor there is profile of the number of the offenders of child sexual abuse and the sanctions imposed. Instead, the data of offenders only contains the numbers of minor and adult prisoners and detainees. The numbers of the child sexual abuse victims according to KPAI data for 2011 and 2014 are 216 and 656, respectively. Figure 2 below shows the growth of child sexual abuse victims which tended to decreased from 2011 to 2014 while sexual abuses for 2011 to 2014 were fluctuating.

Moreover, in relation to the imposition of penal provisions against the offenders of child sexual abuse in Indonesia, the result of a case study reveals that there is a problem in our criminal justice system, failing to effectively try and punish the offenders. Many judges adjudicate legal cases without taking victim's rights into account. Apparently the restoration of the victim's rights is the responsibility of his or her family only. Criminal law apparently has no perspective about the offender's liability to restore the victim's rights resulting from the crime he or she committed (Eddyono, 2016:3-4). Several examples of Supreme Court's criminal verdicts against the offenders of child sexual abuse from 2011 to 2015 were listed in table 4.below.

Table 4. Examples of Supreme Court's Verdicts on Child Sexual Abuse

\begin{tabular}{|c|c|c|c|}
\hline No & Case & Year & Criminal Sanction \\
\hline 1 & $\begin{array}{l}\text { Sexual abuse } \\
\text { by a man (19) } \\
\text { against a girl } \\
\text { (16) in } 2010 \text { in } \\
\text { North Tomohon, } \\
\text { Tondano } \\
\text { regency. }\end{array}$ & 2011 & $\begin{array}{l}5 \text { years in jail and a fine of } \\
\text { Rp } 60,000,000 \text {; subsidiary } \\
\text { of } 3 \text { months in jail }\end{array}$ \\
\hline 2 & $\begin{array}{l}\text { Sexual abuse by } \\
\text { a man teacher } \\
\text { (50) against a } \\
\text { girl ( } 7 \text { ) in } 2011 \\
\text { in Langkat } \\
\text { Regency. }\end{array}$ & 2012 & 4 years in jail \\
\hline 3 & $\begin{array}{l}\text { Sexual abuse by } \\
\text { a father against } \\
\text { his biological } \\
\text { daughter making } \\
\text { her pregnant in } \\
2011 \text { in Batang } \\
\text { Regency }\end{array}$ & 2012 & $\begin{array}{l}10 \text { years in jail and a } \\
\text { fine of Rp } 60,000,000 \text {; } \\
\text { subsidiary of } 6 \text { months } \\
\text { in jail }\end{array}$ \\
\hline 4 & $\begin{array}{l}\text { Sexual abuse } \\
\text { by a boy (16) } \\
\text { against a girl } \\
\text { (15) in Bandung } \\
\text { Regency. }\end{array}$ & 2014 & $\begin{array}{l}1 \text { year and } 2 \text { months } \\
\text { in jail and a fine of } \\
\text { Rp500,000,000; subsidiary } \\
\text { of } 1 \text { year in jail }\end{array}$ \\
\hline 5 & $\begin{array}{l}\text { Sexual abuse by } \\
\text { a father against } \\
\text { his daughter } \\
\text { (3) in } 2015 \text { in } \\
\text { Yogyakarta }\end{array}$ & 2015 & $\begin{array}{l}5 \text { years in jail and a fine of } \\
\text { Rp } 60,000,000 \text {; subsidiary } \\
\text { of } 3 \text { months in jail }\end{array}$ \\
\hline
\end{tabular}

Source: processed from http:/putusan.mahkamahagung.go.id/

Moreover, according to Padjadjaran University's expert of criminal law, AgustinusPohan, based on his research, aggravations of sentences in the provisions of criminal law are not followed by the imposition of maximal punishment by courts against offenders. Threatened harsh punishments in criminal code would not automatically reduce crime levels. Mild court verdicts lead offenders or potential offenders to think that sentences will remain mild though their threatened punishments are harsh. Therefore, it is law enforcement that needs to receive more attention (https://m.tempo.co).

Based on the description above, the output of children handling policy implemented currently 
is generally still less effective in terms of both prevention and law enforcement in punishing the offenders.

\section{Development of Alternative Model of the Handling of Child Sexual Abuse in Indonesia}

Based on the result of analysis described earlier, it was found out that child sexual abuse handling policy applied currently is generally still less effective in terms of both prevention and law enforcement in punishing the offenders. Related to Castration Perpu, here are listed some applications of Easton's and Ripley' models in the case of issuance of Castration Perpu in a bid to handle child sexual abuse in Indonesia:

Table 5. Applications of Easton's and Ripley' models in the case of issuance of Castration Perpu in a bid to handle child sexual abuse in Indonesia

\begin{tabular}{|c|c|c|}
\hline No & Aspect & Scope \\
\hline 1. & $\begin{array}{l}\text { Policy } \\
\text { sphere }\end{array}$ & $\begin{array}{l}\text { - Political structure is dominated by } \\
\text { those politicians who are inclined to } \\
\text { back up the government. } \\
\text { - President Jokowi has authority to take } \\
\text { decisions concerning the problems } \\
\text { of child sexual abuse in Indonesia as } \\
\text { ones that fall into a category of urgent } \\
\text { extraordinary situation. } \\
\text { - The role of KPAI supported by } \\
\text { some relevant ministers (Minister } \\
\text { of Social Affairs and Minister of } \\
\text { PPPA) is quite strong to support } \\
\text { proclaiming child sexual abuse as an } \\
\text { extraordinary crime. } \\
\text { - Non-government organizations } \\
\text { (NGOs) play no role in policy } \\
\text { making. } \\
\text { - There is no higher education or other } \\
\text { organization/institution involved in } \\
\text { developing a scientific study relating } \\
\text { to the policy making. }\end{array}$ \\
\hline 2. & $\begin{array}{l}\text { Agenda } \\
\text { setting }\end{array}$ & $\begin{array}{l}\text { The president swiftly responds to } \\
\text { the discourses on the aggravation of } \\
\text { punishments against the offenders of } \\
\text { child sexual abuse by promising to } \\
\text { give a solution as soon as possible. } \\
\text { - KPAI most actively urges that } \\
\text { Castration Perpu be issued, by taking } \\
\text { actions and exposing to mass media } \\
\text { various problems related to child } \\
\text { sexual abuse. }\end{array}$ \\
\hline 3. & $\begin{array}{l}\text { Formulation } \\
\text { and } \\
\text { legitimacy }\end{array}$ & $\begin{array}{l}\text { - The related ministers conduct studies } \\
\text { limited at ministerial level only. } \\
\text { - The ministers agree upon } \\
\text { aggravating punishments against } \\
\text { the offenders of child sexual abuse } \\
\text { and urge the issuance of Castration } \\
\text { Perpu. } \\
\text { - The President issued Castration } \\
\text { Perpu where it is stipulated that basic } \\
\text { sentence against the offenders of child } \\
\text { sexual abuse is imprisonment of no } \\
\text { less than } 5 \text { (five) years and no more } \\
\text { than } 20 \text { (twenty) years, life sentence, } \\
\text { and death penalty, and additional } \\
\text { punishments including publication of } \\
\text { the identity of the offender, chemical } \\
\text { castration, and attachment of electronic } \\
\text { detector. } \\
\text { - Lawmakers (DPR) have ratified the } \\
\text { draft Castration Perpu to be a Law. }\end{array}$ \\
\hline
\end{tabular}

Source: result of data processing.
The results of analysis on the implementation of the currently prevailing policies and the planned implementation of Castration Perpu disclosed that the policies have not yet provided a strong legal certainty in punishing child sexual abuse in Indonesia. World Rape Statistic, reporting rapes in different states around the world, has proved that either death penalty or castration punishment has been actually ineffective. Issued twiceyearly, it revealed that the states which have applied either death penalty or castration punishment even ranked top ten states with highest numbers of cases in the world. Currently, there are 10 states applying death penalty and 20 states applying castration punishment against rapists. The ten states applying death penalty are: China, Afghanistan, Arab Emirate Union, Egypt, Bangladesh, Iran, Saudi Arabia, India, Pakistan and North Korea. And the 20 states applying castration punishment against rapists are 9 in Europe, 9 in United States, one in Latin America, and one in East Asia. The nine European states are England, Poland, Russia, Germany, Republic of Czechoslovakia, Denmark, Swedia, and Spain. The nine states in United States are California, Florida, Georgia, Iowa, Louisiana, Montana, Oregon, Texas and Wisconsin. The states in Latin America and East Asia are Argentina and South Korea, respectively. World Rape Statistic 2012 noted that the top 10 states with the highest rape cases in the world are: United Stated at the top, followed by Africa, Swedia, India, England, Germany, French, Canada, Sri Lanka and Ethiopia. Moreover, World Rape Statistic 2014 disclosed that the top 10 states with the highest rape cases are India, Spain, Israel, United States, Swedia, Belgium, Argentina, Germany, and Switzerland. The World Rape Statistic data confirms that an assumption that applying castration punishment can result in a deterrent effect is just a myth. Some states that apply either death sentence or castration punishment also admit that the decreasing numbers of the reported rapes do not represent the real situation, because many cases of rapes have gone unreported, especially if the offender is one of the family members (Eddyono, 2016:21-22).

Based on the analysis results, a systems approach can be applied to develop an alternative model of child sexual abuse handling policy. In this case, there are four elements that need attention, namely:

1. Environment. which potentially influence or are related to the incidences of child abuses can be distinguished into two: (1) family and social environment consisting of parents (father-mother), family/relatives, teachers/ school sphere, schoolmates, playmates, and other adult persons and (2) policy environment relating to the policy that the government is applying now in handling the problems of child sexual abuse (Suradi,2013:187).

2. Input. The input here is related to agenda setting, i.e., the government attitudes on the problems of child sexual abuse thus far and mobilization of supports/ 
demands relating to child sexual abuse. In this case, both family and social environment and the government respond to child sexual abuses that have occurred thus far, before and after their occurrences. Before the occurrence of any crime, the environment has to make social intervention in form of a series of activities carried out in systematical and planned ways in handling child sexual abuse by preventive activities by optimizing their own function and role in providing children with protection from sexually abusing actions. After the occurrence of any crime, the environment should make social interventions in form of social rehabilitation, i.e., a series of activities carried out to restore physical, behavioral, cognitive, and social-emotional (psychological) conditions. Besides, in relation to child sexual abuse, the environment should confirm that there has been child sexual abuse by reporting it according to fact available for it to be processed legally in conformity with the prevailing legislations.

3. Political system. Political system here is related to how do the political system process demands/supports on handling child sexual abuse by policy formulation and legitimacy. In this case, the government, by existing politic structure, immediately processes demands/supports on handling child sexual abuse by policy formulation and legitimacy thus far applied. To do a policy reformulation, the government should evaluate its policy regularly based on comprehensive research evidence and accompanied with valid data and evidence, so that the output of the formulated policy would be more effective in handling child sexual abuse.

4. Output. The output of public policy processes is in form of legal provisions (legal product) laid down for handling child sexual abuse in form of law and others. Menurut Sitompul (2015:55) faktor Undang-Undang dalam pemberian sanksi (hukuman) pidana kepada pelaku tindakan kekerasan seksual merupakan salah satu faktor yang mempengaruhi agar penegakan hukum dapat berjalan dengan lancar dan penanggulangan kejahatan kekerasan seksual berdampak positif. The legal provisions relating to the handling of child sexual abuse should be oriented to aggravation of punishment that may deter the offender from repeating the crime. In this case, the government should apply an aggravation of punishment in form of imprisonment of 20 years in minimum and life sentence in maximum, by urging judges and other law enforcers to consistently punish as harsh as possible the offenders of child sexual abuse such as imprisonment of no longer than 20 years and life sentence. If the harshest sentences have been imposed then additional punishments like detector attachment and particularly chemical castration are no longer needed, while additional punishment of the publication of the offender's identity may be considered. It should also be supported by mapping full data (personal identity, background of the crime committed, etc.) of the offenders of child sexual abuse available thus far, and by periodically evaluating the offender data.

5. Feedback. The feedback here is related to the feedback from the policy output, i.e., related to the implementation of child sexual abuse handling policy, whether it is or not effective in handling child sexual abuse.

\section{CONCLUSION}

Based on the research findings it could be disclosed that the output of child sexual abuse handling policy implemented currently was generally still ineffective in both prevention and law enforcement in punishing the offenders. Therefore, a model of child sexual abuse handling policy in Indonesia by a systems approach can be made as an alternative model of policy handling child sexual abuse in Indonesia. The model emphasizes five fundamental elements of policy formulation, namely: (1) environment, i.e., family and social environment and policy environment, (2) input, i.e., government attitudes and family and social environment on making interventions to child sexual abuse before and after occurring, (3) Political system, i.e., the government should reformulate the policies implemented by policy evaluation regularly and based on research evidence, (4) output, i.e., legal provisions (legal products) oriented to punishment aggravation and law enforcement by imposing 20-year imprisonment or life sentence and the publication of the offender identity to deter the offender from repeating the crime, and (5) feedback, i.e., the feedback from the policy process output, relating to the implementation of child sexual abuse handling policy, whether it is or not effective in handling child sexual abuse.

\section{REFERENCES}

Achdiat dan Mulyana, Y. (2017). Model Kebijakan Peningkatan Laporan Kematian Dalam Administrasi Kependudukan Dan Catatan Sipil di Kabupaten Bandung Barat Sosiohumaniora, Volume 19 No. 2 Juli 2017: 140 - 148

Buchari, A. (2016). Implementasi E-Service Pada Organisasi Publik Di Bidang Pelayanan Publik Di Kelurahan Cibangkong Kecamatan Batununggal Kota Bandung, Sosiohumaniora, Volume 18 No. 3 Nopember 2016 : 235 - 239

Creswell, JW., (2016). Research Design, Pendekatan Metode Kualitatif, Kuantitatif dan Campuran Edisi Keempat, Yogyakarta: Pustaka Pelajar. 
Dunn, W., (2003). Pengantar Analisis Kebijakan Publik, Yogyakarta: Gadjah Mada University Press.

Eddyono, SW. (2016). Menguji Euforia Kebiri: Catatan Kritis atas Rencana Kebijakan Kebiri (Chemical Castration) Bagi Pelaku Kejahatan Seksual Anak di Indonesia, Jakarta: Institute for Criminal Justice Reform (ECPAT) Indonesia.

Direktori Putusan Mahkamah Agung RI, http:// putusan.mahkamahagung.go.id/ diakses pada tanggal 8 November 2016

DPR Sahkan Perppu Perlindungan Anak menjadi UU http://www.bbc.com/ indonesia/berita indonesia/2016/10/161012_indonesia perppu_perlindungan_anak_sah diakses pada tanggal 10 November 2016

Fisher, F. (2015). Hand Book Analisis Kebijakan Publik Teori, Politik dan Metode, Bandung: Nusa Media.

Indiahono, D. (2009). Kebijakan Publik Berbasis Dynamic Policy Analysys. Yogyakarta: Penerbit Gava Media.

Komnas PA, Catat Ratusan Kekerasan Seksual Anak, http://m.republika.co.id/ berita /nasional/ umum/16/05/07/o6sy28359-komnas-pa-catatratusan-kekerasn-seksual-anak diakses pada 21 Juni 2016

Naim, A. (2015). Profil Anak Indonesia 2015, Jakarta: Kementrian Pemberdayaan Perempuan dan Perlindungan Anak (KPP\&PA).

Negara dengan Kasus Pemerkosaan Tertinggi, http:// www.koran sindo.com/ news.php? $r=0 \& n=17 \&$ date $=2016-05-04$ diakses pada 6 November 2016

Nugroho, R. (2014). Public Policy. Jakarta: PT. Elex Multimedia.

Pemerkosaan, Berjamaah, - Indonesia Darurat Kekerasan Seksual, http://www.dw.com/id/ pemerkosaanberjamaah-indonesia-darurat-kekerasanseksual/a-19233807 diakses pada 21 Juni 2016.

Perpu, Kebiri Hukuman Kekerasan Seksual Tak Segalak Aturan, https://m.tempo. co/read/ news/2016/05/24/063773634/perpu-kebirihukuman-kekerasan-seksual-tak-segalakaturan diakses pada tanggal 21 Juni 2016

Pohan, A. (2016). Pertanggungjawaban Pidana Korporasi dan Implemtasi Perma 13. Universitas Parahyangan.

Rincian Data Kasus Berdasarkan Klaster Perlindungan Anak 2011-2016, http://bankdata. kpai.go.id/ tabulasi-data/data-kasus-per-tahun/rinciandata-kasus-berdasarkan-klaster-perlindungananak-2011-2016 diakses pada tanggal 21 Juli 2016.

Sitompul, AH. (2015). Kajian Hukum Tentang Tindak Kekerasan Seksual Terhadap Anak di Indonesia. Lex Crimen Vol. IV/No. 1/JanMar/2015.

Sirait, A.M. (2016). Pelanggaran UU Sistem Peradilan Pidana Anak. Komisi Perlindungan Anak Indonesia (KPAI).

Suradi. (2013). Problema dan Solusi Strategis Kekerasan Terhadap Anak, Informasi Vol.18, No.02 Tahun 2013

Suharsaputra, U. (2012). Metode Penelitian Kuantitatif, Kualitatif dan Tindakan, Bandung: PT Refika Aditama.

Widodo, J. (2016) Kejahatan Seksual Anak adalah Kejahatan Luar Biasa, http://presidenri. go.id/kabar-presiden/kegiatan-kepresidenan/ presiden-jokowi-kejahatan-seksual-terhadapanak-adalah-kejahatan-luar-biasa.html diakses pada tanggal 21 Juni 2016

Winarno, B. (2012). Kebijakan Publik (Teori, Proses dan Studi Kasus), Jakarta: CAPS.

Wollmann, H, (2009). Local Governance Reform in Global Perpective, Urban And Regional Research International.

Yusuf, H. (2012). Profil Anak Indonesia 2012, Jakarta: Kementrian Pemberdayaan Perempuan dan Perlindungan Anak (KPP\&PA).

Zainuddin, M. (2015). Kebijakan Hukum Pidana dalam Rangka Penanggulangan Kejahatan Pedofilia, Semarang: Universitas Diponegoro. 